\title{
The Impact of Covid-19 Pandemic on Students' Learning Outcome in Higher Education
}

\author{
Andi Rahman 1 \\ DOI: $10.35445 /$ alishlah.v13i2.974
}

\begin{abstract}
Article Info
Abstract

Keywords: Higher Education; Learning Outcome; Covid-19 Pandemic; Students

The current Covid-19 pandemic has had many effects on human life globally, including the implementation of education. This study aimed to obtain the impact of the Covid-19 pandemic on learning outcomes in higher education. The research method used is a cross-sectional study. The data were taken from the test results at the end of the lecture, observations, and interviews. The research was conducted at the University of Muhammadiyah Lampung, IPDN Jatinangor Campus, and the Ahmad Dahlan Institute of Technology and Business, with 120 students participating. The data analysis technique used the percentage technique and cross-tabulation. The study results concluded that student learning outcomes decreased in the 2020-2021 academic year compared to the 2019-2020 academic year. The decline in learning outcomes includes knowledge, skills, and psychology. This finding has implications for the understanding of education personnel regarding online teaching and learning design during the Covid-19 pandemic.
\end{abstract}

Kata kunci: Perguruan Tinggi; Hasil Belajar; Pandemi Covid-19; Mahasiswa

\begin{abstract}
Abstrak
Pandemi Covid-19 saat ini telah memberikan banyak pengaruh terhadap kehidupan manusia di dunia termasuk pada penyelenggaraan pendidikan. Tujuan penelitian ini adalah untuk mendapatkan dampak pandemic Covid-19 terhadap hasil belajar di perguruan tinggi. Metode penelitian yang digunakan adalah cross-sectional study. Data diambil hasil tes di akhir perkuliahan, observasi, dan wawancara. Penelitian dilakukan di Universitas Muhammadiyah Lampung, Kampus IPDN Jatinangor, dan Institut Teknologi dan Bisnis Ahmad Dahlan dengan jumlah partisipan 120 mahasiswa. Teknik analisis data menggunakan teknik persentase dan tabulasi silang. Hasil penelitian menyimpulkan bahwa hasil belajar mahasiswa mengalami penurunan pada tahun akademik 2020-2021 dibandingkan dengan tahun akademik 2019-2020. Penurunan hasil belajar meliputi pengetahuan, keterampilan dan psikologi. Temuan ini memberikan implikasi pada pemahaman tenaga pendidikan terkait dengan rancangan pengajaran dan pembelajaran daring di masa pandemic Covid-19.
\end{abstract}

\footnotetext{
${ }^{1}$ Manajemen Pendidikan, Universitas PGRI Palembang, Indonesia Email: andiplg25@gmail.com
} 


\section{INTRODUCTION}

In March 2020, the Indonesian government issued a policy to close activities in schools and universities due to the spread of the Covid-19 virus. Even the government did a lockdown to limit everyone's activities. The impact of the Covid-19 pandemic is not only on the health sector but also the process of providing education. To prevent the virus from spreading more widely, the government issued a policy to change face-to-face teaching to online teaching from elementary school to university levels to achieve educational goals (Bubb \& Jones, 2020). To achieve the goal of providing education, educational institutions do not only need technological facilities; support from all parties is needed, including the professionalism of educators (Pratiwi \& Murdiono, 2020). Various digital platforms are recommended to implement teaching and learning, and educators must adapt to the use of Information and Communication Technology (König et al., 2020). The use of technology plays an important role in students' cognitive engagement and academic performance (Patricia Aguilera-Hermida, 2020).

From this explanation, it is known that the process of changing offline learning to online in the Covid-19 pandemic era is not an easy thing. The university must be ready with all facilities related to the application of technology, the competence of educators in the use of technology, or the readiness of teaching materials by the concept of online learning. If this is not carefully prepared, then the educational goals cannot be achieved, or student learning outcomes cannot be by the curriculum designed at the university and is not by the standards of current needs in the global era.

Currently, the Covid-19 pandemic has had a significant impact on teaching and learning outcomes. From the results of Bao's research, he concluded that online education is currently the impact of the Covid-19 pandemic. There are five high impact principles for online education: (a) high relevance between online learning design and student learning, (b) effective delivery of online learning information, (c) adequate support provided by faculty and teaching assistants to students; (d) high-quality participation to increase the breadth and depth of student learning, and (e) contingency plans to deal with unexpected incidents from online education platforms (Bao, 2020). During school closures, students use social media to continue their studies and find out more information about the COVID-19 outbreak (Radwan et al., 2020). Therefore, to support the success of distance learning during the pandemic, collaboration with parents is needed. The presence of parents can be a companion for students if there is a technology problem (Ferraro et al., 2020)

Educators are also required to prepare students to become tough students and build their abilities to remain strong and optimistic individuals to successfully pass the current online learning period (Rahiem, 2021). Even for some students who have a high level of enthusiasm for learning, the concept of online learning also has a positive influence, such as flexible study time (Mulyani et al., 2021). However, another study found that not all students like online learning because they think it is ineffective. Many factors of ineffectiveness are related to social, economic, and cultural in online learning activities in various regions in Indonesia (Febrianto et al., 2020).

From previous research, it is known that the Covid-19 pandemic has had many impacts on human life, including the process of providing education. The impacts that appear are different and have their uniqueness according to the conditions of each region. However, this study has a different orientation to determine the impact of the Covid-19 pandemic on the implementation of education at universities. It has a different focus as a gap from the study that wants to know. The gap in this research is the impact of the Covid-19 pandemic on student learning outcomes focused on learning outcomes for one year during the pandemic in higher education compared to the year before the pandemic. The identified learning outcomes are related to student behavior or attitudes during the learning process. In addition, there are various activities related to the online learning process, both during the online class learning process, student activity in collecting assignments, or learning outcomes from final tests obtained by students. In addition, to understand the decline in learning outcomes, this study also understands the factors that affect learning outcomes. 
Therefore, this research has a considerable degree of urgency towards understanding the impact of the Covid-19 pandemic because the impacts resulting from the pandemic period can be used as a guide for designing online teaching and learning appropriate for the pandemic period. So, this study aims to obtain the impact of the Covid-19 pandemic on student learning outcomes in higher education. This research can be recommended as material for analyzing the needs of online teaching and learning concepts for the pandemic. In addition, the results of this study are also expected to contribute to educators' understanding of directing student behavior to carry out learning activities that can achieve learning objectives in this online class. As we know that online and offline classroom situations have different academic atmospheres. So, this study describes the results related to the academic atmosphere that must be built in the online classroom.

\section{METHODS}

The study used a cross-sectional study. A cross-sectional research design is a type of observational research design. This study examines the phenomenon of the impact of the Covid-19 pandemic on student learning outcomes in higher education. In cross-sectional studies, researchers measure outcomes and exposures in study participants simultaneously (Setia, 2016). Participants were taken randomly, and students had received online learning during the Covid-19 pandemic for one year from September 2020 to June 2021. Participants were taken from 3 universities: Muhammadiyah University Lampung, IPDN Jatinangor Campus, and the Ahmad Dahlan Institute of Technology and Business. 120 participants were taken from each university. The method used to determine participants is a simple random sample (Taylor et al., 2004). Research subjects are selected according to the class under study as a whole undifferentiated data.

The research carried out is relatively efficient because data collection activities are carried out at the end of the lecture. Primary data is taken from the value of the end-of-semester learning outcomes in the odd semester and even semester of the 2020-2021 academic year. The data was taken from the results of the final test in the class used as research subjects. The data taken is the average score for the two semesters. In addition, secondary data was taken from observations and interviews with students to support the impact of the Covid-19 pandemic on learning outcomes. The data analysis technique used is the percentage technique and cross-tabulation. Percentage analysis is a method used to see the frequency of respondents' answers and phenomena in the field. Cross tabulation is the easiest way to see associations in several data by calculating percentages.

\section{FINDINGS AND DISCUSSION}

The results of the end-of-semester test data analysis from the even and odd semesters of the 2020-2021 academic year experienced a significant decrease compared to the final score in the 20192020 academic year. The following is a graph comparing average scores and percentages that have been compared during the last two years of teaching and learning activities.

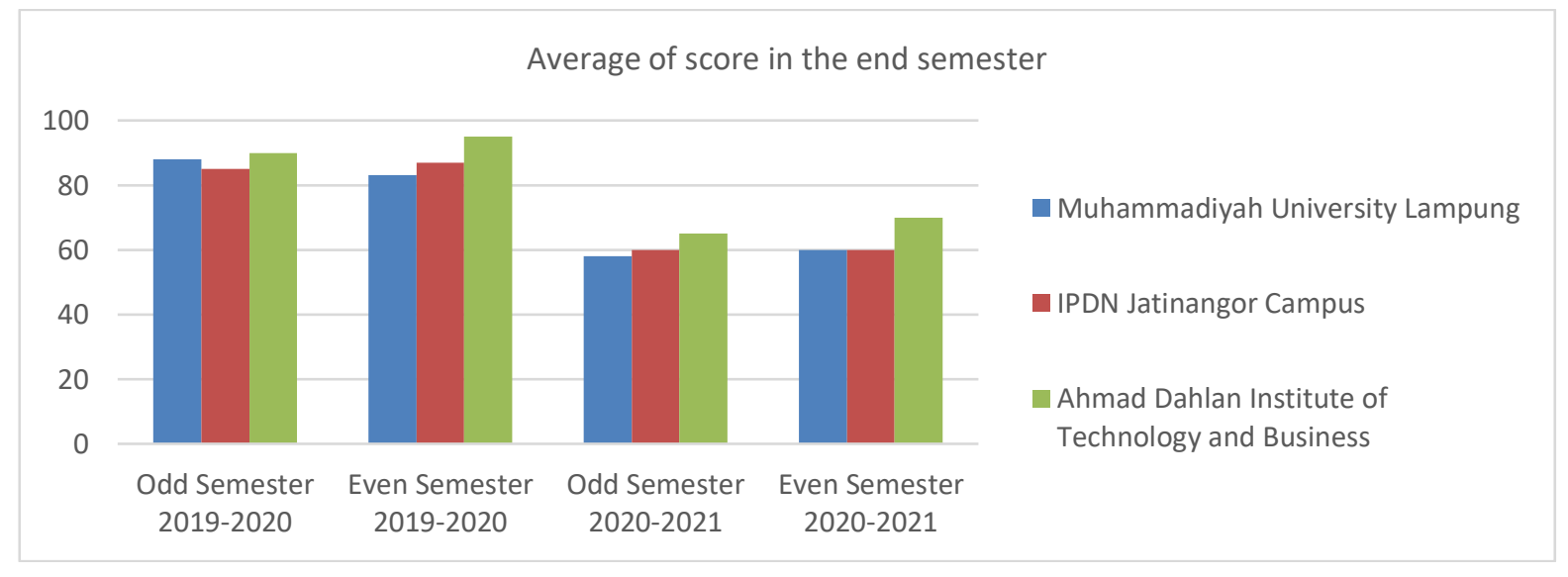

Graph 1. Final Semester Average for 2 Years 
Graph 1 is known that student learning outcomes in the 2019-2020 academic year are better than the 2020-2021 academic year. From the three campuses that have been analyzed, it can be concluded that every student from three universities experienced a decrease in average scores before and after the Covid-19 pandemic. The average value in the 2019-2020 academic year, both odd and even semesters, is in grade B or A (Good and Very Good), from 80-90. Meanwhile, in the 2020-2021 academic year or during the Covid-19 pandemic, the average grade of students experienced a drastic decline because the average score was in grade $\mathrm{C}$ (enough), which was between the range of 58-70. This decrease is quite large, and the value of each individual has decreased.

From the observation data when the class lasted for one year during the pandemic, which was carried out via zoom, there were several findings of a decrease in learning outcomes, namely;

1. Students are less interactive

2. Students tend to be passive

3. Students have a less stable level of motivation

4. Students are not on time to collect assignments

5. Students tend to wait for the lecturer's explanation rather than taking the initiative to discuss Meanwhile, the results of the interviews were analyzed, and the percentages are presented in the following table;

Table 1. The Result of the Interview

\begin{tabular}{llcc}
\hline & \multicolumn{1}{c}{ Item of interview } & Frequency & $\%$ \\
\hline 1 & Students prefer learning in class & 90 & $75 \%$ \\
2 & Students prefer distance learning & 58 & $48 \%$ \\
3 & Students feel that online learning time is less efficient & 93 & $78 \%$ \\
4 & Your attention to learning activities in class is the same when online and offline & 55 & $46 \%$ \\
5 & Your study time at home when online classes are the same as offline classes & 60 & $50 \%$ \\
6 & You are always on time to collect assignments from the lecturer & 55 & $46 \%$ \\
7 & You face many difficulties in completing tasks & 103 & $86 \%$ \\
8 & You ask a lot of lecturers in the WhatsApp group when you have difficulty & 50 & $42 \%$ \\
& completing assignments & 90 & $75 \%$ \\
9 & You are silent even though you don't understand the material or assignments & & \\
& both in WhatsApp Groups and online classes & 60 & $50 \%$ \\
\hline
\end{tabular}

The results of interviews support data analysis of test results for one year. Overall, students feel dissatisfied and inefficient online learning activities because they have difficulty understanding the material. Students prefer offline classes to online. This is also because online classes often experience internet network problems. The overall data shows that the Covid-19 pandemic has caused a decrease in student learning outcomes. The spread of the Covid-19 virus is not only on learning outcomes but also on students' psychology. Learning outcomes that have decreased are seen in the aspects of skills and knowledge. While psychologically also experienced a decrease in learning motivation, emotional, social interaction, and the desire to achieve better learning outcomes. Even worse, psychological consequences of the impact of implementing education during the Covid-19 pandemic, such as anxiety, depression, and stress (Zhang et al., 2020). This crisis has created an atmosphere of uncertainty, fear, and psychological changes in behavior among students that cannot be avoided (Pandita et al., 2021; Aucejo et al., 2020).

Several factors that cause a decrease in learning outcomes from interviews, observations, and test results are; 1) students rarely take online lectures, 2) communication is less interactive, 3) students experience a decrease in motivation, 4) students are passive and tend to wait for lecturers' instructions, and 5) passive students in WhatsApp Groups. Therefore, this study provides input for improving online learning activities, namely:

1. Lecturers should always build more intense communication in WhatsApp Groups.

2. Lecturers must use teaching and learning strategies in online classes that invite students to ask questions actively, or discuss. 
3. Lecturers can use various technological media such as interesting videos, animations, or powerpoints

4. Lecturers can make students presenters in presenting material

5. Designing materials and test questions (as an evaluation of learning outcomes) by online class conditions.

6. Lecturers can use rewards as a consequence of student activity in online classes.

7. Lecturers must be able to build communication and cooperation with parents of students so that the supervision and encouragement of learning motivation can occur in two directions.

Thus, the government and educational institutions must design long-term strategies to address a resilient education system with a futuristic orientation (Khan \& Ahmed, 2021). The development of online learning strategies must also be part of the planning for the development of the education system so that the impacts resulting from online learning activities can still achieve the goals of providing education such as offline learning activities (Elzainy et al., 2020). From the perspective of students and educators, all parties must struggle with the transition from offline to online classes (Audet et al., 2021). Meanwhile, from parents' perspective, online learning during the Covid-19 pandemic also has a negative impact. They tend to reject and even reject online learning for three main reasons: lack of online learning, inadequate self-regulation of children, and their lack of time and professional knowledge in supporting children's online learning (Dong et al., 2020).

COVID-19 has also had an impact on the mentality of students for a deep level of emotional stability. This undesirable state of affairs is combined with health-related fears and uncertainty about the future. Students are carried away with various negative feelings, including frustration, boredom, fatigue, anxiety, stress, depression, and anger (Camacho-Zuñiga et al., 2021). Therefore, educational institutions need to remain aware of mental health that can affect stability during the teaching and learning process. Universities must be prepared to face all kinds of psychological impacts during the online process in the classroom. It should inform policymakers in academia to reflect on the psychological needs of students in virtual teaching environments (Shah et al., 2021). In addition to this, students also often pay less attention when online classes occur (Thind et al., 2021). So, during the covid-19 pandemic, educators must understand the desires and perspectives of students towards online learning. They are interested in online learning that can be accessed flexibly, anywhere, and everywhere (Huang, 2020).

\section{CONCLUSION}

The results of the data analysis concluded that the Covid-19 pandemic had a considerable impact on student learning outcomes and psychology. This condition is a consideration for teachers in designing and building communication in the classroom. Teachers have a greater responsibility to build better online classes by involving collaboration from students, parents, colleagues, and various learning resources. The results of this study can be used as a reference for educators' implementation of online learning. Educators at the university must consider some things in student behavior in understanding the basic concepts of online learning assisted by technology devices. Educators must know the background of the student's personality in learning as a form or way to foster a sense of comfort during online learning. In addition, the various technological applications used must also be by the needs of students and have appropriate learning strategies with appropriate technological media for each lesson.

This research also still has limitations because it understands the impact of the Covid-19 pandemic on learning outcomes from the results of the learning evaluation at the end of the semester. This limitation can still be developed by assessing various aspects or parties, such as psychological factors, the learning environment at home, and parents. Thus, research can still be continued by developing aspects or components that affect student learning outcomes. Therefore, the results of this study suggest that educators should be able to build cooperation between all parties in building online classes and designing learning strategies from the perspective of student needs or the 
background and learning environment of students, current conditions related to the teaching and learning process, and industry. In addition, every teaching staff can also use multimedia technology related to the latest developments in science and technology.

\section{REFERENCES}

Aucejo, E. M., French, J., Ugalde Araya, M. P., \& Zafar, B. (2020). The impact of COVID-19 on student experiences and expectations: Evidence from a survey. Journal of Public Economics, 191, 104271. https://doi.org/10.1016/J.JPUBECO.2020.104271

Audet, É. C., Levine, S. L., Metin, E., Koestner, S., \& Barcan, S. (2021). Zooming their way through university: Which Big 5 traits facilitated students' adjustment to online courses during the COVID-19 pandemic. Personality and Individual Differences, 180, 110969. https://doi.org/10.1016/J.PAID.2021.110969

Bao, W. (2020). COVID -19 and online teaching in higher education: A case study of Peking University . Human Behavior and Emerging Technologies, 2(2), 113-115. https://doi.org/10.1002/HBE2.191

Bubb, S., \& Jones, M. A. (2020). Learning from the COVID-19 home-schooling experience: Listening to pupils, parents/carers and teachers. Improving Schools, 23(3), 209-222. https://doi.org/10.1177/1365480220958797

Camacho-Zuñiga, C., Pego, L., Escamilla, J., \& Hosseini, S. (2021). The impact of the COVID-19 pandemic on students' feelings at high school, undergraduate, and postgraduate levels. Heliyon, 7(3), e06465. https://doi.org/10.1016/J.HELIYON.2021.E06465

Dong, C., Cao, S., \& Li, H. (2020). Young children's online learning during COVID-19 pandemic: Chinese parents' beliefs and attitudes. Children and Youth Services Review, 118, 105440. https://doi.org/10.1016/J.CHILDYOUTH.2020.105440

Elzainy, A., El Sadik, A., \& Al Abdulmonem, W. (2020). Experience of e-learning and online assessment during the COVID-19 pandemic at the College of Medicine, Qassim University. Journal of Taibah University Medical Sciences, 15(6), 456-462. https://doi.org/10.1016/J.JTUMED.2020.09.005

Febrianto, P. T., Mas'udah, S., \& Megasari, L. A. (2020). Implementation of online learning during the covid-19 pandemic on Madura Island, Indonesia. International Journal of Learning, Teaching and Educational Research, 19(8), 233-254. https://doi.org/10.26803/ijlter.19.8.13

Ferraro, F. V., Ambra, F. I., Aruta, L., \& Iavarone, M. L. (2020). Distance learning in the covid-19 era: Perceptions in Southern Italy. Education Sciences, 1O(12), 1-10. https://doi.org/10.3390/educsci10120355

Huang, Y. (2020). Research on Online Education in the Midst of the COVID-19 Pandemic. Journal of Advances in Education Research, 5(2). https://doi.org/10.22606/JAER.2020.52005

Khan, M. J., \& Ahmed, J. (2021). Child education in the time of pandemic: Learning loss and dropout. Children and Youth Services Review, 127, 106065. https://doi.org/10.1016/J.CHILDYOUTH.2021.106065

König, J., Jäger-Biela, D. J., \& Glutsch, N. (2020). Adapting to online teaching during COVID-19 school closure: teacher education and teacher competence effects among early career teachers in Germany. European Journal of Teacher Education, 43(4), 608-622. https://doi.org/10.1080/02619768.2020.1809650

Mulyani, Fidyati, Suryani, Suri, M., \& Halimatussakdiah. (2021). University students' perceptions through e-learning implementation during covid-19 pandemic: Positive or negative features dominate? Studies in English Language and Education, 8(1), 197-211. https://doi.org/10.24815/siele.v8i1.17628

Pandita, S., Mishra, H. G., \& Chib, S. (2021). Psychological impact of covid-19 crises on students through the lens of Stimulus-Organism-Response (SOR) model. Children and Youth Services Review, 12O, 105783. https://doi.org/10.1016/J.CHILDYOUTH.2020.105783

Patricia Aguilera-Hermida, A. (2020). College students' use and acceptance of emergency online learning due to COVID-19. International Journal of Educational Research Open, 1, 100011. https://doi.org/10.1016/j.ijedro.2020.100011

Pratiwi, P. H., \& Murdiono, M. (2020). The Role of Parents in Strengthening the Character of Honesty When Learning at Home during the Covid-19 Pandemic. Proceeding Book of the 3rd International Conference on Multidisciplinary Research, 3(2). 
Radwan, E., Radwan, A., \& Radwan, W. (2020). The role of social media in spreading panic among primary and secondary school students during the COVID-19 pandemic: An online questionnaire study from the Gaza Strip, Palestine. Heliyon, 6(12), e05807. https://doi.org/10.1016/J.HELIYON.2020.E05807

Rahiem, M. D. H. (2021). Remaining motivated despite the limitations: University students' learning propensity during the COVID-19 pandemic. Children and Youth Services Review, 12O, 105802. https://doi.org/10.1016/J.CHILDYOUTH.2020.105802

Setia, M. S. (2016). Methodology Series Module 3: Cross-sectional Studies. Indian Journal of Dermatology, 61(3), 261. https://doi.org/10.4103/0019-5154.182410

Shah, S. S., Shah, A. A., Memon, F., Kemal, A. A., \& Soomro, A. (2021). Online learning during the COVID-19 pandemic: Applying the self-determination theory in the 'new normal.' Revista de Psicodidáctica (English Ed.), 26(2), 168-177. https://doi.org/10.1016/J.PSICOE.2020.12.003

Taylor, K., Nettleton, S., \& Harding, G. (2004). Sociology for Pharmacists Second Edition. Taylor \& Francis.

Thind, A. S., Singh, H., Yerramsetty, D. L., \& Pandeya, D. R. (2021). Impact of the COVID-19 pandemic on Caribbean Medical Students: A cross-sectional study. Annals of Medicine and Surgery, 67, 102515. https://doi.org/10.1016/J.AMSU.2021.102515

Zhang, C., Ye, M., Fu, Y., Yang, M., Luo, F., Yuan, J., \& Tao, Q. (2020). The Psychological Impact of the COVID-19 Pandemic on Teenagers in China. Journal of Adolescent Health, 67(6), 747755. https://doi.org/10.1016/J.JADOHEALTH.2020.08.026 